Pál Sáry

The legal protection of environment

in ancient Rome
Journal of Agricultural and

Environmental Law

$29 / 2020$

\title{
Pál SÁRY* \\ The legal protection of environment in ancient Rome
}

\begin{abstract}
The paper wants to give an overview of the moral and legal rules which protected the natural and built environment in ancient Rome. These rules prove that environment protection is not a modern invention. A bonus et diligens pater familias was morally obliged to cultivate his own agricultural land carefully. Both air and water pollution was legally sanctioned. A house-owner had to keep his own building in good condition. Each person was to keep the street outside his own house in repair and clean. Demolition of both private and public buildings was strictly restricted. It is true that in ancient Rome environment protection was not full scope (e.g., animal protection was absent from Roman law), but many elements of environment were legally protected.
\end{abstract}

Keywords: environment protection, Roman law, agriculture, silviculture, air pollution, water pollution, waste, road repairs, maintenance, demolition, protection of monuments

\section{Protection of agricultural lands and forests}

Behaviour of the Roman citizens was regulated by legal, religious and moral rules. The moral rules primarily regulated how a pater familias had to act at home, in his own house, in his own land. Consequently, these rules described the characteristics of a good father, a good husband, a good slave-holder, a good farmer. The keeping of the moral rules was supervised by the censors. Moreover, the censors made lists of the different groups of the citizens. This latter activity of them was combined with the moral control: the censors could delete the name of any immoral senator from the list of the senate, the name of any immoral knight from the list of the equestrian order, and the name of any immoral citizen from the list of the centuries and the tribes. The citizens who were excluded from the centuries and the tribes got into the group of the aerarians. The legal capacity of the aerarians was limited: they could not be present at the assemblies, they had neither active nor passive right to vote, they could not serve in the army, and they had to pay a special poll-tax.

According to the ancient moral rules of the Roman society, the farmers had to cultivate carefully their ploughlands, vineyards and fruit-gardens. ${ }^{1}$ It was also supervised by the censors who put the careless farmers on the list of the aerarians. In his work entitled Noctes Atticae, Aulus Gellius writes the following: "Si quis agrum suum passus fuerat sordescere eumque indiligenter curabat ac neque araverat neque purgaverat, sive quis arborem suam vineamque habuerat derelictui, non id sine poena fuit, sed erat opus

Pál Sáry: The legal protection of environment in ancient Rome. Journal of Agricultural and Environmental Law ISSN 1788-6171, 2020 Vol. XV No. 29 pp. 199-216, https://doi.org/10.21029/JAEL.2020.29.199

* dr. jur., PhD, dr. habil., full professor, Department of Roman Law, Faculty of Law, University of Miskolc, e-mail: jogsary@uni-miskolc.hu.

${ }^{1}$ Cf. Astin 1988, 22.; Baltrusch 1989, 17.; El Beheiri 2012, 120, 151.

https://doi.org/10.21029/JAEL.2020.29.199 
Pál Sáry

The legal protection of environment

in ancient Rome
Journal of Agricultural and

Environmental Law

$29 / 2020$

censorium, censoresque aerarium faciebant." ("If anyone had allowed his land to run to waste and was not giving it sufficient attention, if he had neither ploughed nor weeded it, or if anyone had neglected his orchard or vineyard, such conduct did not go unpunished, but it was taken up by the censors, who reduced such a man to the lowest class of citizens." $)^{2}$

Pliny the Elder also confirms that careless cultivation of the land was regarded an offence by the censors: 'agrum male colere censorium probrum iudicabatur.' 3 Consequently, ownership of agricultural land involved certain obligations, and the state imposed sanctions for neglect of these duties. In other words, the rights of the owner of an agricultural land were restricted by the obligation of careful cultivation.

Of course, the usufructuary, the lessee and the emphyteuta were also obliged to cultivate the land carefully. The usufructuary had to cultivate the land in the proper way. Ulpian writes the following: "Item si fundi usus fructus sit legatus, quidquid in fundo nascitur, quidquid inde percipi potest, ipsius fructus est, sic tamen ut boni viri arbitratu fruatur. Nam et Celsus libro octavo decimo digestorum scribit cogi eum posse recte colere." ("Similary, if a usufruct of land is left by way of legacy, whatever is produced on the land, whatever can be taken from it, counts as fruits of the land, providing, however, that the usufructuary takes them in the way that a careful man would think right. Indeed, Celsus states in the eighteenth book of his Digest that he can be compelled to cultivate the land in the proper way.") 4

We know from Ulpian that the usufructuary was not allowed to cut down fruit trees. ${ }^{5}$ Moreover, as Paul writes, he had to plant other trees in place of those that had died. 6 According to the opinion of Ulpian, the usufructuary can open mines, providing that this activity do not prejudice the cultivation of the land. ${ }^{7}$

We can find similar rules in the Justinianic Institutes: "Sed si gregis usumfructum quis habeat, in locum demortuorum capitum ex fetu fructuarius summittere debet, ut et Iuliano visum est, et in vinearum demortuarum vel arborum locum alias debet substituere. Recte enim colere debet et quasi bonus paterfamilias uti." ("The usufructuary of a flock, as Julian held, ought to replace any of the animals which die from the young of the rest, and, if his usufruct be of land, to replace dead vines or trees; for it is his duty to cultivate according to law and use them like a careful head of a family.") 8

The Romans differentiated between coppice-woods (silva caedua) and not coppice-woods (silva non caedua). According to Gaius, "Silva caedua est, ut quidam putant, quae in hoc habetur, ut caederetur. Servius eam esse, quae succisa rursus ex stirpibus aut radicibus renascitur." ("Wood for timber' is as some people think a wood

${ }^{2}$ Gell. NA 4,12 (tr. J. C. Rolfe).

3 Plin. NH 18,3,11.

${ }^{4}$ Ulp. D. 7,1,9 pr. (tr. D. Fergus).

${ }_{5}^{5}$ Ulp. D. 7,1,13,4.

6 Paul. D. $7,1,18$.

${ }^{7}$ Ulp. D. 7,1,13,5.

8 Inst. 2,1,38 (tr. J. B. Moyle). 
which is owned for this purpose, namely to be felled. Servius thinks that it is a wood which grows again from the stock or the root when it is cut.") 9

If the object of the usufruct was a wood, the rights of the usufructuary depended on the type of the wood. Pomponius writes the following: "Ex silva caedua pedamenta et ramos ex arbore usufructuarium sumpturum: ex non caedua in vineam sumpturum, dum ne fundum deteriorem faciat." ("The usufructuary may take props and branches from trees from coppice-wood. From a wood which is not a coppice-wood he may take what he needs for his vineyard, as long as he does not impoverish the estate." ${ }^{10}$

The lessee also was obliged to cultivate the agricultural land carefully. In his comprehensive treatise entitled The Roman Colonate, Clausing states that "The most important obligation of the tenant was the proper cultivation of the soil."11 With regard to the obligations of the lessee, Gaius writes the following: "Conductor omnia secundum legem conductionis facere debet. Et ante omnia colonus curare debet, ut opera rustica suo quoque tempore faciat, ne intempestiva cultura deteriorem fundum faceret." ("The lessee should perform everything in accord with the clauses of the lease. Above all, the tenant farmer should see to it that he does farm work during his term as well, so that he did not make the farm worth less by his unseasonable cultivation.") ${ }^{12}$

If a farm was leased with rental payments spread over a five-year period, the owner, as Paul writes, could bring an action at once if the farm tenant abandoned the cultivation of the farm: "Si [...] fundus in quinquennium pensionibus locatus sit, potest dominus, si deserueret [...] fundi culturam colonus vel inquilinus, cum eis statim agere." 13 As Du Plessis pointed out on the basis of further textes of the Digest, "a conductor of agricultural land was contractually obliged to cultivate it to preserve its fertility and failure to do so constituted grounds for the termination of the contract."14

In case of lease of a woodland, the lessee had to conserve the condition of the wood. For the sake of it, he had to arrange also for proper guarding of the forest. We are told the following by Alfenus: "In lege locationis scriptum erat: 'Redemptor silvam ne caedito neve cingito neve deurito neve quem cingere caedere urere sinito.' Quaerebatur, utrum redemptor, si quem quid earum rerum facere vidisset, prohibere deberet an etiam ita silvam custodire, ne quis id facere possit. Respondi verbum sinere utramque habere significationem, sed locatorem potius id videri voluisse, ut redemptor non solum, si quem casu vidisset silvam caedere, prohiberet, sed uti curaret et daret operam, ne quis caederet." (“A lease clause stated: 'The lessee of public land shall not fell nor bark nor burn the woodland, nor allow anyone to back or fell or burn.' Should the lessee stop someone if he saw him doing one of this things, or should he in addition guard the woodland to prevent anyone's being able to do it? I responded that the word 'allow' has both meanings, but that on the whole the lessor seems to have desired not

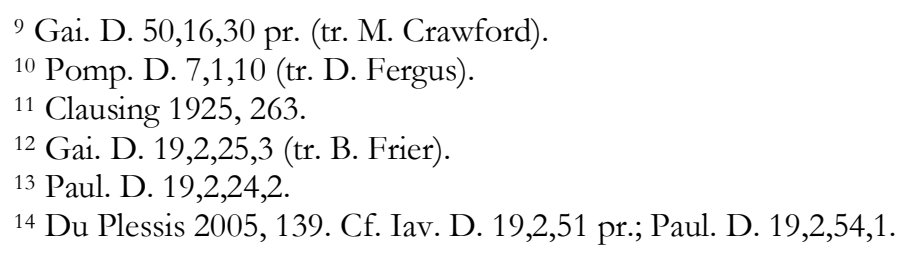


Pál Sáry

The legal protection of environment

in ancient Rome
Journal of Agricultural and

Environmental Law

$29 / 2020$

only that the lessee stop someone if he chanced to see him felling the woodland but also that he take care and make an active effort to prevent someone's felling it.") ${ }^{15}$

The term emphyteusis derived from the Greek verb emphuteuein (to plant in). It indicates us that the emphyteuta was bound to plant and improve the agricultural land. ${ }^{16}$ As we can read in the Novels of Justinian, the emphyteuta might lose all of his rights by damaging the land. ${ }^{17}$

It is worth adding that the illegal cutting down of the trees of somebody else realized a private delict. According to Pliny the Elder, "Fuit et arborum cura legibus priscis, cautumque est XII tabulis ut, qui iniuria cecidisset alienas, lueret in singulas aeris XXV." ("The ancient laws also took the trees under their protection; and by the Twelve Tables it was enacted, that he who should wrongfully cut down trees belonging to another person, should pay twenty-five asses for each.") ${ }^{18}$ At the interpretation of the law, this rule was extended by the pontifices to the case of cutting down of vinestocks. ${ }^{19}$

The action of the Twelve Tables obtained the name actio de arboribus succisis, as mentioned by Gaius. ${ }^{20}$ Later, another action, the actio arborum furtim caesarum was introduced by the praetor. ${ }^{21}$ This praetorian innovation was necessary, because the legal fact regulated by the Twelve Tables was too narrow and the penalty of 25 asses became too low in the second half of the Republic. ${ }^{22}$

According to Gaius, "Si colonus sit, qui ceciderit arbores, etiam ex locato cum eo agi potest. Plane una actione contentus esse debet actor." ("If it be an agricultural tenant who felled the trees, he will also be liable to the action on letting. But, of course, the plaintiff will have to be content with one action.") ${ }^{23}$ It means that a lessee who cut the trees could be sued by both the actio arborum furtim caesarum and the actio locati, but the lessor had to choose between the two actions.

In the classical period cutting down another person's trees or vine-stocks became a public crime. This conclusion can be drawn from the following words of Gaius: "Sciendum est autem eos, qui arbores et maxime vites ceciderint, etiam tamquam latrones puniri." ("But it should be known that those who cut down trees, especially vines, are punishable also as brigands." ${ }^{24}$

Finally, we may mention that in case of cutting trees the interdictum quod vi aut clam could also be used. This interdict, as Berger writes, was issued against a person who forcibly (vi) or secretly (clam) did a 'work' on the claimant's land. The work (opus) was here conceived in the broadest sense of any act done which changes the state of

15 Alf. D. 19,2,29 (tr. B. Frier).

${ }^{16}$ Cf. Johnston 1940, 323.

${ }_{17}$ Cf. Nov. 7,3,2; 120,8 .

18 Plin. NH 17,1,7 (tr. J. Bostock \& H. T. Riley). According to Pólay, the illegal eradication (succissio) of the most valuable things of the farming plot (olive-trees, vine-stocks) constituted an iniuria-delict against the head of the house-community. See Pólay 1986, 71.

${ }^{19}$ Cf. Gai. 4,11; Ulp. D. 47,7,3 pr.

${ }^{20}$ Gai. $4,11$.

${ }^{21}$ Cf. D. 47,7.

22 Cf. Lenel 1927, 337.

${ }^{23}$ Gai. D. 47,7,9 (tr. J. A. C. Thomas).

${ }^{24}$ Gai. D. 47,7,2 (tr. J. A. C. Thomas). 
Pál Sáry

The legal protection of environment

in ancient Rome
Journal of Agricultural and

Environmental Law

$29 / 2020$

the land or its surface, such as cutting trees. The aim of the interdict was restoration to the former state by the defendant himself or at his expense. ${ }^{25}$ If the trees provided some amenity, their value for pleasure could also be counted. Paul writes the following: "Si quis vi aut clam arbores non frugiferas ceciderit, veluti cupressos, domino dumtaxat competit interdictum. sed si amoenitas quaedam ex huiusmodi arboribus praestetur, potest dici et fructuarii interesse propter voluptatem et gestationem et esse huic interdicto locum." ("If anyone by force or stealth cuts trees that bear no fruit, such as cypresses, the owner will still be able to have recourse to the interdict. But if some amenity is also provided by these trees, it can be said that the usufructuary has an interest too on account of their value for pleasure and promenades and that the interdict is available to him also." $)^{26}$

\section{Protection of the purity of air and water}

The emission of smoke is the most typical form of the air pollution. In the Digest of Justinian we can read about a case in which a certain Cerellius Vitalis complained about smoke emitted by a cheese shop (taberna casiaria) that was situated just below his estate. Ulpian reports the following: "Aristo Cerellio Vitali respondit non putare se ex taberna casiaria fumum in superiora aedificia iure immitti posse, nisi ei rei servitutem talem admittit. [...] Posse igitur superiorem cum inferiore agere ius illi non esse id ita facere. [...] Dicit igitur Aristo eum, qui tabernam casiariam a minturnensibus conduxit, a superiore prohiberi posse fumum immittere..." ("Aristo states in an opinion given to Cerellius Vitalis that he does not think that smoke can lawfully be discharged from a cheese shop onto the buildings above it, unless they are subject to a servitude to this effect, and this is admitted. [...] Thus, the owner of the upper property can bring an action against the owner of the lower, asserting that the latter does not have the right to act in this way. [...] Hence, Aristo holds that the man who leased a cheese shop from the authorities of Minturnae, can be prevented from discharging smoke by the owner of the building above it...") ${ }^{27}$

Consequently, as among others Wacke states, the owner of the upper property could by way of an actio negatoria assert that the cheese shop did not have the right to discharge the smoke. ${ }^{28}$ Ulpian adds a further note to the case: "Sed et interdictum uti possidetis poterit locum habere, si quis prohibeatur, qualiter velit, suo uti." ("Further, the interdict for the possession of land may be employed, if a man is prevented from using his own land in the way he wishes.") Thus, the owner of the upper land was able to use also the interdictum uti possidetis, by which remedy the magistrate could prohibit the emission of smoke.

In certain cases emission of smoke constituted a delict. According to the opinion of Javolenus, the person who emitted smoke to the land of his neighbour with the intention to insult (iniuriae faciendae causa) could be sued in the action for injury (actio iniuriarum). He writes the following: "Si inferiorum dominus aedium superioris

\footnotetext{
${ }_{25}$ Berger 1953, 511.

26 Paul. D. 43,24,16,1 (tr. T. Braun).

${ }^{27}$ Ulp. D. 8,5,8,5 (tr. D. Fergus).

28 Wacke 2002, 7.
} 
Pál Sáry

The legal protection of environment

in ancient Rome
Journal of Agricultural and

Environmental Law

$29 / 2020$

vicini fumigandi causa fumum faceret..., negat Labeo iniuriarum agi posse: quod falsum puto, si tamen iniuriae faciendae causa immittitur." "“If the owner of the lower premises create smoke to fumigate those of his neighbour above..., Labeo says that the action for insult does not lie. I think this wrong, if it were done with the intention to insult."') 29

Smoke could cause the death of bees. The person who killed another's bees by smoking committed the delict of 'loss wrongfully caused' (damnum iniuria datum), and for this reason he could be sued in an actio in factum legis Aquiliae. According to Ulpian, "Si quis fumo facto apes alienas fugaverit vel etiam necaverit, magis causam mortis praestitisse videtur quam occidisse, et ideo in factum actione tenebitur." ("If someone drives away, or even kills, another's bees by making smoke, he seems rather to have provided the cause of their death than directly to have killed them, and so he will be liable to an action in factum." $)^{30}$

Finally, in connection with the emission of smoke, it is worth to mention the question of cremation. As we know, the Twelve Tables prohibited burials and cremations within the city walls. ${ }^{31}$ On the basis of the words of Isidore of Seville, ${ }^{32}$ Van Den Bergh considers that these prohibitions were for purposes of prevention of pollution. ${ }^{33}$

We can add to this that the mentioned provisions of the Twelve Tables had not only hygienic purposes. As Robinson writes, these prohibitions of the law were for aims of keeping 'land free for building or public places in the developing City,' and fire prevention. ${ }^{34}$ Quoting the words of the Twelve Tables, Cicero himself notes that cremation is prohibited because of the danger of fire. ${ }^{35}$

According to the testimony of an inscription, at around $80 \mathrm{BC}$ the praetor urbanus prohibited to make places for cremation, and to throw out excrements or dead animals in he city and vicinity of Rome. The text of the inscription is as follows: "L[ucius] Sentius C[ai] f[ilius] pr[aetor] de sen[atus] sent[entia] loca terminanda coer[avit] b[onum] f[actum] nei quis intra terminos propius urbem ustrinam fecisse velit neive stercus cadaver iniecisse velit." ("L. Sentius, son of Gaius, praetor, in accordance with a motion of the senate supervised the marking off of this area with boundarystones. A deed well done! Let no-one be minded to make a cremation-place or cast dung or a carcass within the boundary-stones on the side nearer to the city." $)^{36}$

\footnotetext{
${ }^{29}$ Iav. D. 47,10,44 (tr. J. A. C. Thomas). Cf. Pólay 1986, 164-165.

${ }^{30}$ Ulp. D. 9,2,49 pr. (tr. C. Kolbert).

${ }^{31}$ Cf. Cic. leg. 2,23,58 (= XII tab. 10,1): "Hominem mortuum ... in urbe ne sepelito neve urito." ("A dead man ... shall not be buried or burned inside the city.")

32 Isid. etym. 15,11,1: "Prius autem quisque in domo suo sepeliebatur. Postea vetitum est legibus, ne foetore ipso corpora viventium contacta inficerentur." ("Originally people were buried in their own homes. Later this was prohibited by law, so that the bodies of the living would not be infected by contact with the stench.”).

33 Van Den Bergh 1999, 505.

34 Robinson 1975, 176.

35 Cic. leg. 2,23,58: "Credo vel propter ignis periculum." ("I suppose the latter is on account of danger of fire.").

36 ILS 8208. Cf. Robinson, 1992, 108; Salomies 2015, 161-162.
} 
The emission of bed smell is another frequent form of the air pollution. The bed smell is often caused by rotting organic refuses which are dangerous to health. We can read about such problems in the ancient sources. The Younger Pliny as a governor wrote the following to the emperor Trajan: "The city of Amastris, Sir, which is both elegantly and finely built, boasts among its most striking features a very beautiful and lengthy street, down one side of which, to its full extent, runs what is called a river, but it is really a sewer of the foulest kind. This is not only an eyesore because it is so disgusting to look at, but it is a danger to health from its shocking smells. For these reasons, both for the sake of health and appearance, it ought to be covered over, and this will be done if you give leave, while we will take care that the money shall be forthcoming for so important and necessary a work." 37 Trajan gave permission to have the stream covered if it was a danger to health, but left it to Pliny to find the money to pay for the work: "It stands to reason, my dear Pliny, that the stream which flows through the city of Amastris should be covered over, if by remaining uncovered it endangers the public health. I feel certain that, with your usual diligence, you will take care that the money for the work will be forthcoming." 38

The Romans knew well that the filth of the sewers seriously endangered the public health. The person who was hindered by force from repairing or cleaning of a sewer could claim from the praetor to issue the interdictum de cloacis. In this case the magistratus drew up as follows: "Quo minus illi cloacam quae ex aedibus eius in tuas pertinet, qua de agitur, purgare reficere liceat, vim fieri veto." ("I forbid the use of force to prevent you from cleaning and repairing the drain in question, which reaches from his house to yours.") ${ }^{39}$

There were two interdicta de cloacis: one for prohibition, the other for restitution. ${ }^{40}$ According to the comment of Ulpian, "Curavit autem praetor per haec interdicta, ut cloacae et purgentur et reficiantur, quorum utrumque et ad salubritatem civitatium et ad tutelam pertinet: nam et caelum pestilens et ruinas minantur immunditiae cloacarum, si non reficiantur." ("The praetor has taken care by means of these interdicts for the cleaning and the repair of drains. Both pertain to the health of civitates and to safety. For drains choked with filth threaten pestilence of the atmosphere and ruin, if they are not repaired." $)^{41}$

We can find some cases in the Digest, which are related to water pollution. Ulpian writes the following: "Apud Trebatium relatum est eum, in cuius fundo aqua oritur, fullonicas circa fontem instituisse et ex his aquam in fundum vicini immittere coepisse: ait ergo non teneri eum aquae pluviae arcendae actione. Si tamen aquam conrivat vel si spurcam quis immittat, posse eum impediri plerisque placuit." ("It is recorded in Trebatius that someone who had a spring on his land established a fuller's shop at it and began to cause the water there to flow onto his neighbour's property. Trebatius says that he is not liable to an action to ward off rainwater.

\footnotetext{
37 Plin. ep. 10,98 (tr. Firth J B).

38 Plin. ep. 10,99 (tr. Firth J B). Cf. Liebeschuetz 2015, 13; Havlíček \& Morcinek 2016, 41-42; Fiorentini 2018, 326-327.

${ }^{39}$ Ulp. D. 43,23,1 pr. (tr. T. Braun).

${ }^{40}$ Cf. Ulp. D. $43,23,1,1$.

${ }^{41}$ Ulp. D. 43,23,1,2 (tr. T. Braun).
} 
However, many authorities accept that if he channeled the water into one stream or introduced any dirt into it, he can be restrained.") ${ }^{42}$ Consequently, as Flohr states on the basis of this text, the owner of a fullery could get into trouble when the wastewater from his workshop was too dirty and caused pollution on a neighbouring property; the owner of a fullery could in such cases be obliged to take measures to prevent it. ${ }^{43}$

As we know, the fullers (fullones) were employed in washing and cleaning dirty garments. They worked with urine, by which the dirt was more easily separated from the clothes, and which they got from the public toilets (latrinae). ${ }^{44}$ In the course of this work a large quantity of wastewater was producted. According to the above-cited text, the fullers were not allowed to introduce any dirt into the water which flowed onto the neighbour's land. The jurist do not tell us which action could be brought in such a case of pollution. The actio aquae pluviae arcendae could not be used, because this action, as Ulpian writes, was available when someone caused rainwater (aqua pluvia) to flow elsewhere than in its natural course, for example, if by allowing it to run, he maked the flow greater or faster or stronger than usual or if by blocking the flow he caused an overflow. 45 According to Wacke, the injured neighbour could bring an actio negatoria to prevent the fullers from the further water pollution. ${ }^{46} \mathrm{I}$ think this opinion is acceptable, but I would add to it again that the injured party was able to use also the interdictum uti possidetis, by which remedy he could achieve his aim in a more quickly and simply way.

The interdictum quod vi aut clam was the most comprehensive legal remedy available for asserting rights against a neighbour. ${ }^{47}$ This interdict could be issued when someone poured something into his neighbour's well in order to pollute the water. ${ }^{48}$ Ulpian writes the following: "Is qui in puteum vicini aliquid effuderit, ut hoc facto aquam corrumperet, ait Labeo interdicto quod vi aut clam eum teneri: portio enim agri videtur aqua viva, quemadmodum si quid operis in aqua fecisset." ("Labeo says that anyone who pours something into the well of his neighbour, in order to spoil the water by doing so, will be liable under the interdict quod vi aut clam, because living water is considered to constitute part of the land, and this is just as if he had constructed a new work in the water.") ${ }^{49}$

In imperial times, the affronts contrary good morals were treated as extraordinary crimes (crimina extraordinaria) and prosecuted through public accusation. Since water pollution was also regarded such an injury, it was submitted to criminal prosecution. We are told by Paul the following: "Fit iniuria contra bonos mores, veluti si quis fimo corrupto aliquem perfuderit, caeno luto oblinierit, aquas spurcaverit, fistulas lacus quidve aliud ad iniuriam publicam contaminaverit: in quos graviter animadverti solet." ("It is an affront contrary to sound morals when a person showers

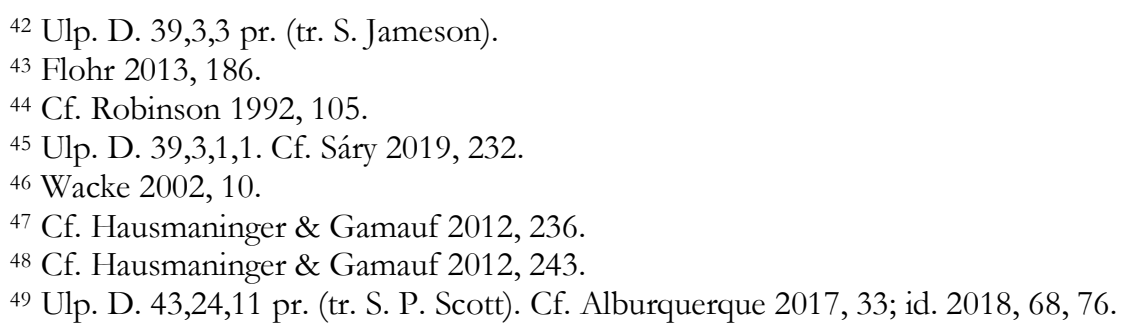


Pál Sáry

The legal protection of environment

in ancient Rome
Journal of Agricultural and

Environmental Law

$29 / 2020$

another with excrement, smears him with mud and filth, defiles waters, water pipes, or a lake, or contaminates anything to the detriment of the public; against such persons, stern action is taken." $)^{50}$

For protection of the purity of water, the springs and aqueducts had to be cleaned. The person who had right to draw water in another's land or to lead cattles to another's land to water could clean and repair the spring (fons). These servitudes (servitus aquae haustus and servitus pecoris ad aquam appulsus) were protected by the interdictum de fonte. When it was issued, the praetor, among others, said: "Quo minus fontem, quo de agitur, purges reficias, ut aquam coercere utique ea possis, dum ne aliter utaris, atque uti hoc anno non vi non clam non precario ab illo usus es, vim fieri veto." ("I forbid the use of force to prevent you from cleaning and repairing the spring in question, so that you may extract water from it and use it, provided that you use it in no other way than you did this year not by force, stealth, or precarium." $)^{51}$

The person who had right to lead water (in other words, who had a servitus aquaeductus) could repair and clean the bed (rivus) of the water: this right was protected by the interdictum de rivis. Granting this legal remedy the praetor said: "Rivos specus septa reficere purgare aquae ducendae causa quo minus liceat illi, dum ne aliter aquam ducat, quam uti priore aestate non vi non clam non precario a te duxit, vim fieri veto." "“I forbid the use of force to prevent such a one from repairing or cleaning for the purpose of drawing off water, watercourses, culverts, or sluices, provided that he does not draw off water in any other way than he drew from you last summer not by force, stealth, or precarium.” $)^{52}$

Special rules were applied to the public aqueducts. We are told by Frontinus that some laws enacted as follows: "Ne quis aquam oletato dolo malo, ubi publice saliet. Si quis oletarit, sestertiorum decem milium multa esto." ("No one shall with malice pollute the waters where they issue publicly. Should any one pollute them, his fine shall be ten thousand sestertii.") ${ }^{53}$ Those over whose land a public aqueduct passed were obliged to clean the aqueduct regularly. Those who omitted this duty were to be punished by confiscation of their land. ${ }^{54}$

\section{Protection of built environment}

According to the lex Iulia municipalis of Julius Caesar, the administration of the repair and maintenance of the public roads of the city of Rome (and within one mile of the capital) belonged to the aediles. ${ }^{55}$ The owner of a building fronting on any road had to maintain that road to the satisfaction of the aedile to whom that part of the city had been assigned. ${ }^{56}$ If the owner had failed to do his duty the aedile was to set a contract for the maintenance of that road. The aedile made the contract publicly in the forum

\footnotetext{
${ }^{50}$ Paul. D. 47,11,1,1 (tr. J. A. C. Thomas). Cf. Pólay 1986, 185.

51 Ulp. D. 43,22,1,6 (tr. T. Braun).

${ }^{52}$ Ulp. D. 43,21,1 pr. (tr. T. Braun).

${ }^{53}$ Front. aq. 2,97 (tr. C. E. Bennett). Cf. Alburquerque 2017, 32-33; id. 2018, 67.

${ }^{54}$ Cf. CTh 15,2,1 = C. 11,43(42),1.

${ }_{55}$ Tab. Heracl. 24-28.

56 Tab. Heracl. 20-21.
} 
through the urban quaestor (or whoever was in charge of the treasury). The owner had to pay a fixed sum to the contractor within a certain period, otherwise he had to pay one and a half times that sum to him. ${ }^{57}$

According to the same law, the aediles and their subordinates - the four men for cleaning the roads within the city of Rome (quattuorviri viis in urbe purgandis) and the two men for cleaning the roads within one mile of the capital (duoviri viis extra urbem purgandis) - was to see to the cleaning of the public roads and had full authority in such matter. ${ }^{58}$ The owner of a building fronting on a footpath (semita) had to keep that footpath paved with continuous stone slabs along his frontage to the satisfaction of the competent aedile. ${ }^{59}$

Cassius Dio tells us that in 33 BC Agrippa as aedile "without taking anything from the public treasury repaired all the public buildings and all the streets, cleaned out the sewers, and sailed through them underground into the Tiber." 60 Under Caligula still the aediles were in charge of keeping the roads and alleys of the city of Rome clean. According to Suetonius, "when Vespasian was aedile, Gaius Caesar, incensed at his neglect of his duty of cleaning the streets, ordered that he be covered with mud, which the soldiers accordingly heaped into the bosom of his purple-bordered toga..."11 Suetonius further informs us that Caligula "was so lazy and luxurious that he was carried in a litter by eight bearers, requiring the inhabitants of the towns through which he passed to sweep the roads for him and sprinkle them to lay the dust." 62 We can come to know from a letter of Trajan that those who were condemned to public works (ad opera publica) had 'to clean out the sewers, and to repair the roads and streets.' 63

During the later centuries, the obligations of the urban house-owners gradually increased. First of all, they had to repair their own houses. According to Ulpian, "Praeses provinciae inspectis aedificiis dominos eorum causa cognita reficere ea compellat et adversus detractantem competenti remedio deformitati auxilium ferat." ("A provincial governor ought to compel owners to repair buildings, sufficient ground having been shown on inspection of them. If they refuse, he should by the use of some competent remedy against them patch up the unsightly appearance of the buildings." $)^{64}$

Moreover, the owners had to keep the parts of the streets opposite to their houses clean. Papinian writes as follows: "Vias autem publicas unumquemque iuxta domum suam reficere oportet et canales ex subdiali repurgare et reficere ita, ut vehiculum recte ibi iter facere possit. Qui in conducto habitant, si dominus non reficit, ipse reficiunto et quod impenderint a mercede deducunto." ("Each person is to keep the public street outside his own house in repair and clean out the open gutters and ensure that no vehicle is prevented from access. Occupiers of rented accomodation

\footnotetext{
${ }^{57}$ Tab. Heracl. 32-45. Cf. Robinson, 1992, 51-52; Liebeschuetz 2015, 8.

58 Tab. Heracl. 50-52. Cf. Robinson, 1992, 59-60; Havlíček \& Morcinek 2016, 37.

${ }_{59}$ Tab. Heracl. 53-55.

${ }^{60}$ Dio 49,43 (tr. E. Cary). Cf. Robinson 1992, 53.

${ }^{61}$ Suet. Vesp. 5 (tr. J. C. Rolfe). Dio also tells this story (59,12). Cf. Robinson, 1992, 54.

${ }^{62}$ Suet. Cal. 43 (tr. J. C. Rolfe).

${ }^{63}$ Plin. ep. 10,32 (tr. J. B. Firth). Cf. Liebeshuetz 2015, 7.

${ }^{64}$ Ulp. D. 1,18,7 (tr. D. N. MacCormick). Cf. Salcedo 2018, 175.
} 
Pál Sáry

The legal protection of environment

in ancient Rome
Journal of Agricultural and

Environmental Law

$29 / 2020$

must carry out these repairs themselves if the owner fails to do so and deduct their expenses from the rent." $)^{65}$

To the Italian and provincial cities special officials (curatores rei publicae) were sent by the emperors for the supervision and administration of municipal finances. One of the specified functions of these officials was a responsibility for ensuring that derelict houses were rebuilt. We are told the following by Paul: "Ad curatoris rei publicae officium spectat, ut dirutae domus a dominis extruantur. Domum sumptu publico exstructam, si dominus ad tempus pecuniam impensam cum usuris restituere noluerit, iure eam res publica distrahit." ("The functions of the curator of the respublica include seeing to it that derelict houses are re-erected by their owners. When a house has been re-erected at public expense, the respublica can legally sell it if the owner refuses to return the sum expended plus interest at the proper time.") ${ }^{66}$

In the cities of the Greek-speaking east, the officers charged with the oversight of the streets were called astunomikoi (in Latin translation of Mommsen: curatores urbium). Their duties were summarized by Papinian. The Latin translation of his Greek words is as follows: "Item curam agant, parietes privati quaeve alia circa domus viam attingunt vitiosa ne sint, ut domini aedium sic ut oportet eas commundent et reficiant. Quod si non commundabunt vel non reficient, multanto eos, donec ea firma reddant. Item curam agant, ne quis in viis fodiat neve eas obruat neve quicquam in viis aedificet [...] Ne sinunto autem neque pugnari in viis nec stercus proici nec cadavera nec pelles eo conici." ("And they are to take care that private walls and enclosure walls of houses facing the street are not in bed repair, so that the owners should clean and refurbish them as necessary. If they do not clean or refurbish them, they are to fine them until they make them safe. They are to take care that nobody digs holes in the streets, encumbers them, or builds anything on them. [...] They are not to allow anyone to fight in the streets, or to fling dung, or to throw out any dead animals or skins." $)^{67}$

Public places were protected by the interdictum ne quid in loco publico fiat. According to Ulpian, the praetor said: "Ne quid in loco publico facias inve eum locum immittas, qua ex re quid illi damni detur, praeterquam quod lege senatus consulto edicto decretove principum tibi concessum est." ("You are not to do anything in a public place, or introduce anything into it, which could cause any damage to such a one, except for what has been permitted to you by statute, senatus consultum, or edict, or decree of the emperor.") $)^{68}$

In connection with this interdictum prohibitorium, Ulpian mentions many interesting rules. For example, we can know from him that disfigurement of the city was to be avoided. The jurist writes the following: "Si quis nemine prohibente in publico aedificaverit, non esse eum cogendum tollere, ne ruinis urbs deformetur, et quia prohibitorium est interdictum, non restitutorium. Si tamen obstet id aedificium publico usui, utique is, qui operibus publicis procurat, debebit id deponere, aut si non obstet, solarium ei imponere..." ("If someone builds in a public place and nobody prevents

\footnotetext{
${ }^{65}$ Pap. D. 43,10,1,3 (tr. T. Braun). This fragment of the Digest is Greek; the quoted Latin text is the translation of Theodor Mommsen.

66 Paul. D. 39,2,46 (tr. S. Jameson). Cf. Salcedo 2018, 175.

${ }^{67}$ Pap. D. 43,10,1,1-2.5 (tr. T. Braun). Cf. Robinson 1992, 57-58; Kamińska 2012, 179.

68 Ulp. D. 43,8,2 pr. (tr. T. Braun). Cf. Alburquerque 2017, 37.
} 
him, he cannot then be compelled to demolish, for fear of ruins disfiguring the city and because the interdict is for prohibition, not restitution. But if his building obstructs public use, it must certainly be demolished by the official in charge of public works. If it does not, he must impose a solarium [grount-rent] on it." ${ }^{69}$

A special praetorian interdict, the interdictum de via publica protected the public rural roads. We are told by Ulpian that the praetor said: "In via publica itinereve publico facere immittere quid, quo ea via idve iter deterius sit fiat, veto." ("I forbid doing or introducing anything in a public road or way by which that road or way is or shall be made worse.") 70 According to the comment of the jurist, "Deteriorem autem viam fieri sic accipiendum est, si usus eius ad commeandum corrumpatur, hoc est ad eundum vel agendum, ut, cum plane fuerit, clivosa fiat vel ex molli aspera aut angustior ex latiore aut palustris ex sicca." ("Making a road worse is to be understood to mean impairing its usefulness for traffic, that is, for walking or driving, as when it was level and is made steep, or when it is turned from smooth to rough, from broader to narrower, or from dry to muddy." $)^{71}$

A public road could be deteriorated in many ways. Ulpian mentions a lot of cases: "Si quis cloacam in viam publicam immitteret exque ea re minus habilis via per cloacam fiat, teneri eum Labeo scribit: immisisse enim eum videri. Proinde et si fossam quis in fundo suo fecerit, ut ibi aqua collecta in viam decurrat, hoc interdicto tenebitur: immissum enim habere etiam hunc videri. [...] Hoc interdictum etiam ad ea, quae pascuntur in via publica itinereve publico et deteriorem faciant viam, locum habet." ("If anyone should bring down a drain into a public road and because of this the road is made less fit for use, Labeo writes that he is liable; for he is held to have introduced [something to make the road worse]. So if anyone digs a cutting in his farm, so that water collects there and runs down into the road, his is liable under this edict; for he too is held to have introduced something. [...] This interdict also applies to damage to the road done by animals grazing in a public road or public way." $)^{72}$

According to Ulpian, this interdictum prohibitorium was completed by the praetor with an interdictum restitutorium: "Quod in via publica itinereve publico factum immissum habes, quo ea via idve iter deterius sit fiat, restituas." ("You are to make good whatever you have, that is, done or introduced in a public road or way by which that road or way is or shall be made worse.") ${ }^{73}$ As the jurist writes, "Restituere videtur, qui in pristinum statum reducit: quod fit, sive quis tollit id quod factum est vel reponat quod sublatum est." ("To make good is to restore to its original condition. This is done by removing what has been constracted or replacing what has been removed..." $)^{74}$

\footnotetext{
${ }^{69}$ Ulp. D. 43,8,2,17 (tr. T. Braun).

70 Ulp. D. 43,8,2,20 (tr. T. Braun).

${ }^{71}$ Ulp. D. 43,8,2,32 (tr. T. Braun).

72 Ulp. D. 43,8,2,26-27.30 (tr. T. Braun).

${ }^{73}$ Ulp. D. 43,8,2,35 (tr. T. Braun). Cf. Alburquerque 2017, 39.

${ }^{74}$ Ulp. D. 43,8,2,43 (tr. T. Braun).
} 
The praetor protected those who wanted to repair a public road or way. Ulpian quotes the words of the praetor: "Quo minus illi viam publicam iterve publicum aperire reficere liceat, dum ne ea via idve iter deterius fiat, vim fieri veto." "“I forbid the use of force to prevent such a one from opening up or repairing a public road or way, as long as that road or way is not made worse." $)^{75}$ The jurist comments these words as follows: "Viam aperire est ad veterem altitudinem latitudinemque restituere. Sed et purgare refectionis portio est: purgare autem proprie dicitur ad libramentum proprium redigere sublato eo quod super eam esset. Reficit enim et qui aperit et qui purgat et omnes omnino, qui in pristinum statum reducunt." ("To open up a road is to restore it to its old depth and breadth. It is a part of its repair to clean it. Cleaning it is, properly speaking, to reduce it to its proper level by clearing away all that is upon it. Repair includes opening it up and cleaning it and everything that is done to restore it to its original state.") $)^{76}$

Sacred places were protected by the interdictum ne quid in loco sacro fiat. We are told by Ulpian that the praetor said: "In loco sacro facere inve eum immittere quid veto." ("I forbid doing anything in a sacred place, or introducing anything into it.") 77 According to the comment of the jusrist, "Quod ait praetor, ne quid in loco sacro fiat, non ad hoc pertinet, quod ornamenti causa fit, sed quod deformitatis vel incommodi." ("The praetor's words forbidding the doing of anything in a sacred place apply not to what is done to embellish it, but to its defacement and to nuisance." $)^{78}$

The walls and gates of a town, as inviolable things (res sanctae), also belonged to the things under divine law (res divini iuris). According to Hermogenian, "In muris itemque portis et aliis sanctis locis aliquid facere, ex quo damnum aut incommodum irrogetur, non permittitur." ("To do anything to the walls, doors, and other sacred places that will cause damage or nuisance is not permitted." $)^{79}$ A fire hazard was especially to be avoided in these places. As Paul writes, "Neque muri neque portae habitari sine permissu principis propter fortuita incendia possunt." ("The walls and doors may not be used for habitation without permission of the emperor because of the danger of chance fires."') 80

In the later Roman Empire the compulsory public services (munera publica) were an integral part of the tax system. The repairing of roads and bridges (viarum et pontium sollicitudo) was among these services. ${ }^{81}$

In the Roman Empire demolition of buildings was prohibited or at least restricted by a lot of legal rules. The municipal charter of Terentum (89-62 BC) contained the following provisions: "Nei quis in oppido quod eius municipi e[r]it aedificium detegito neive dem[olito] neive disturbato, nisei quod non deterius restiturus erit, nisei d[e] s[enatus] s[ententia]. Sei quis adversus ea faxit, quant[i] id aedificium $\mathrm{f}[\mathrm{u}]$ erit, tantam pequni[a]m municipio dare damnas esto, eiusque pequniae [que]i volet

\footnotetext{
${ }^{75}$ Ulp. D. 43,8,11,1 pr. (tr. T. Braun).

${ }_{76}$ Ulp. D. 43,8,11,1,1 (tr. T. Braun).

77 Ulp. D. 43,6,1 pr (tr. T. Braun).

78 Ulp. D. 43,6,1,2 (tr. T. Braun).

${ }^{79}$ Herm. D. 43,6,2 (tr. T. Braun).

${ }^{80}$ Paul. D. 43,6,3 (tr. T. Braun).

${ }^{81}$ Cf. CTh 11,16,15.18; 15,3,6.
} 


\section{Pál Sáry \\ The legal protection of environment \\ in ancient Rome}

\section{Journal of Agricultural and \\ Environmental Law \\ $29 / 2020$}

petiti[o] esto." ("No person within the town of the said municipium of Tarentum shall unroof or demolish or dismantle any house without a decree of the senate, unless he shall intend to restore such house to its former condition. Any person acting in violation of this prohibition shall be liable to pay to the municipium a sum of money equivalent to the value of the said house, and may be sued at will by any person for that amount.") 82

The senatus consultum Hosidianum of AD 44 forbade the purchase of buildings with the intention of destroying them for profit (diruendo plus adquirere) from selling the materials. Such a transaction was void, and the buyer had to pay double the price to the fisc as a penalty. ${ }^{83}$ This prohibition was restated by the senatus consultum Volusianum of AD 56.84

Demolition of houses was restricted also by the emperor Hadrian. According to his biography, "he ruled that in no community should any house be demolished for the purpose of transporting any building-materials to another city." 85 We are told by Marcian that the senate prohibited to leave houses for demolition as a legatum or fideicommissum: "Aedes destruendae neque legari neque per fideicommissum relinqui possunt: et ita senatus censuit." 86

In the later Roman Empire the use of spoils from older, unused buildings in new constructions became common. After the victory of Christianity this practice of cannibalizing old buildings included the pagan temples and other ancient monuments of Rome. The officials of the City conceded upon petition the use for construction of stones recovered from demolition of ancient public buildings. This vandalism had to be stopped. In 458 the emperor Majorian forbade the destruction of ancient monuments for the sake of their materials. The constitution, which was addressed to Aemilianus, prefect of Rome, stated the facts: "Aedes si quidem publicas, in quibus omnis Romanae civitatis consistit ornatus, passim dirui plectenda urbani officii suggestione manifestum est. Dum necessaria publico operi saxa finguntur, antiquarum aedium dissipatur speciosa constructio et ut parvum aliquid reparetur, magna diruuntur." ("Indeed, it is manifest that the public buildings, in which the adornment of the entire City of Rome consists are being destroyed everywhere by the punishable recommendation of the office of the prefect of the City. While it is peretended that the stones are necessary for public works, the beautiful structures of the ancient buildings are being scattered, and in order that something small may be repaired, great things are being destroyed.")

In this situation the emperor ordered as follows: "Idcirco generali lege sancimus cuncta aedificia quaeve in templis aliisque monumentis a veteribus condita propter usum vel amoenitatem publicam subrexerunt, ita a nullo destrui..." (“Therefore, by this general law We sanction that all the buildings that have been founded by the ancients as temples and as other monuments and that were constructed for the public use or pleasure shall not be destroyed by any person...") The punishment for judges who had

\footnotetext{
${ }^{82}$ Lex Tar. 32-35 (tr. E. G. Hardy). See FIRA, 121; Hardy 1911, 108. Cf. Robinson 1992, 36; Cappelletti 2017, 62; Barker \& Marano 2017, 840; Salcedo 2018, 177.

83 See FIRA 200. Cf. Barker \& Marano 2017, 841-842; Cappelletti 2017, 64.

84 See FIRA 201. Cf. Barker \& Marano 2017, 842; Cappelletti 2017, 64.

85 SHA Hadr. 18 (tr. D. Magie).

${ }^{86}$ Marci. D. 30,114,9 (tr. T. Braun). Cf. Robinson 1992, 38.
} 
allowed the destruction of ancient public buildings was fifty pounds of gold, while their subordinates were whipped and had both hands amputated. Those who had removed materials from public buildings were to return them. The ancient monuments could be pulled down under very strict conditions, with the permission of the senate and the emperor. ${ }^{87}$

\section{Summary}

In ancient Rome the owners could not be obliged by laws to cultivate their own farms carefully. However, moral rules specified that every farmer was to cultivate his own land with due care. Against those who broke their moral duties the censors applied strict sanctions.

The usufructuaries, lessees and emphyteutas were not only morally but also legally obliged to cultivate the agricultural lands carefully. Although these rules protected basically the rights of the owners, they indirectly served also the protection of the natural environment.

Illegal cutting down of trees of somebody else constituted a delict. The committer could be sued originally by the actio de arboribus succisis of the Law of the Twelve Tables, later by the actio arborum furtim caesarum of the praetorian edict. In such a case the interdictum quod vi aut clam was also appliable; it was aimed at restitution of the former state of things. In imperial law the illegal cutting down of trees or vine-stocks was regarded as a public crime. Basically these rules protected the private ownership, but they indirectly served the protection of the trees, too.

Against the neighbour who emitted thick smoke many kinds of legal remedies (actio negatoria, interdictum uti possidetis, actio iniuriarum, actio in factum legis Aquiliae) could be used, depending on the circumstances of the case. It was prohibited to cremate corpses within the city boundaries. Against the neighbour who continuously polluted the running water also could be applied different types of legal remedies (actio negatoria, interdictum uti possidetis). In case of polluting of a well the interdictum quod vi aut clam could be issued. The person who was prevented from cleaning of a spring, a bed of a water course, or a sewer could use different interdicts (interdictum de fonte, interdictum de rivis, interdictum de cloacis). The owners were obliged to clean the public aqueduct passed over their lands. Those who polluted the water of the aqueduct could receive heavy monetary punishment.

The house-owners were obliged to maintain their own buildings, as well as to repair and clean the part of the street in front of them. To take part in maintaining of the roads and bridges was a public obligation. The sewers were usually cleaned by those who were condemned to public works. Within the town to throw out excrements, dead animals or skins to a public area was prohibited. Public areas, public roads and sacred places were protected by different interdicts (interdictum ne quid in loco publico fiat, interdictum de via publica, interdictum ne quid in loco sacro fiat).

${ }^{87}$ NMaj 4,1 (tr. C. Pharr). Cf. Alchermes 1994, 176-178. 
Pál Sáry

The legal protection of environment

in ancient Rome
Journal of Agricultural and

Environmental Law

$29 / 2020$

Demolition of houses was tied to strict conditions by municipal charters (as, for example, the lex Tarentina). The SC Hosidianum and the SC Volusianum forbade the purchase of houses to demolish them and obtain profit from selling the building materials. A special decree of the emperor Maiorian prohibited demolition of the monuments of Rome.

Consequently, Roman law protected both the natural and built environment by many devices. This protection, however, was not full-scope: animal protection, for example, was wholly missing from the Roman ideas. ${ }^{88}$

${ }^{88}$ It is true that some imperial decrees restricted hunting of lions (cf. CTh 15,11,1), but they did it only to ensure that enough lion would remain for animal fights, in which public shows a huge crowd of wild animals was killed. 
Pál Sáry

The legal protection of environment

in ancient Rome
Journal of Agricultural and

Environmental Law

$29 / 2020$

\section{Bibliography}

1. Alburquerque J M (2017) Algunus fundamentos y convergencias de la experiencia administrativa romana sobre el medio ambiente, los recursos naturales y res publicae, Glossae 14, pp. 28-53.

2. Alburquerque J M (2018) Provisions of Rules of the Roman Administration in Defense of Natural Resources, Res Publicae and the Environment, Ius Romanum 4(1), pp. 62-81.

3. Alchermes J (1994) Spolia in Roman Cities of the Late Empire. Legislative Rationales and Architectural Reuse, Dumbarton Oaks Papers 48, pp. 167-178, doi: $10.2307 / 1291726$.

4. Astin A E (1988) Regimen Morum, The Journal of Roman Studies 78, pp. 14-34, doi: $10.2307 / 301448$.

5. Baltrusch E (1989) Regimen morum. Die Reglementierung des Privatlebens der Senatoren und Ritter in der römischen Republik und frühen Kaiserzeit, Verlag C. H. Beck, München.

6. Barker S J \& Marano Y A (2017) Demolition laws in archaeological context. Legislation and architectural re-use in the Roman building industry, in: Pensabene P, Milella M, Caprioli F (eds.) Decor. Decorazione e architettura nel mondo romano, Roma, pp. 833-850.

7. Berger A (1953) Encyclopedic Dictionary of Roman Law, The American Philosophical Society, Philadelphia, doi: 10.2307/1005773.

8. Cappelletti L (2017) Norme per la tutela degli edifici negli statuti locali (secoli I a.C. - I d.C.), Bullettino dell'istituto di diritto romano 111, pp. 53-74.

9. Clausing R (1925) The Roman Colonate. The Theories of its Origin, Columbia University, New York.

10. Du Plessis P (2005) Subletting and the Roman law of letting and hiring Interpreting C.4.65.6, Revue internationale des droits de l'antiquité 52, pp. 131-144.

11. El Beheiri N (2012) Das »regimen morum« der Zensoren. Die Konstruktion des römischen Gemeinwesens, Duncker \& Humblot, https://doi.org/10.3790/978-3-428-53789-1.

12. Fiorentini M (2018) Cloache e sanità urbana nello specchio del diritto, Index 46, pp. $320-343$.

13. Flohr M (2013) The World of the Fullo. Work, Economy, and Society in Roman Italy, Oxford University Press, Oxford.

14. Hardy E G (1911) Six Roman Laws, The Clarendon Press, Oxford.

15. Hausmaninger H \& Gamauf R (2012) A Casebook on Roman Property Law, Oxford University Press, Oxford.

16. Havlíček F \& Morcinek M (2016) Waste and Pollution in the Ancient Roman Empire, Journal of Landscape Ecology 9(3), pp. 33-49, doi: 10.1515/jlecol-20160013.

17. Johnston W R (1940) Emphyteusis. A Roman 'Perpetual' Tenure, The University of Toronto Law Journal 3(2), pp. 323-347, doi: 10.2307/824317.

18. Kamińska R (2012) 'Totam urbem tuendam esse commissam' (Cic., In Verr. 2,5,36). The aediles as guardians of order in Republican Rome, Zeszyty Prawnicze 12(3), pp. 177-198, doi: 10.21697/zp.2012.12.3.08

19. Lenel O (1927) Das Edictum perpetuum, 3. Aufl., Verlag B. Tauchnitz, Leipzig. 
Pál Sáry

The legal protection of environment in ancient Rome
Journal of Agricultural and

Environmental Law

20. Liebeschuetz W (2015) Rubbish disposal in Greek and Roman cities, in: East and West in Late Antiquity: Invasion, Settlement, Ethnogenesis and Conflicts of Religion, Brill, Leiden, pp. 3-18, https://doi.org/10.1163/9789004289529_002.

21. Pólay E (1986) Iniuria Types in Roman Law, Akadémiai Kiadó, Budapest.

22. Robinson O (1975) The Roman Law on Burials and Burial Grounds, The Irish Jurist 10(1), pp. 175-186.

23. Robinson O F (1992) Ancient Rome. City Planning and Administration, Routledge, London-New York.

24. Salcedo M C J (2018) Initiatives of the Roman Administration and Urban Environment, Ius Romanum 4(1), pp. 162-183.

25. Salomies O (2015) The Roman Republic, in: Bruun C \& Edmondson J (eds.) The Oxford Handbook of Roman Epigraphy, Oxford University Press, Oxford, pp. 153-177, doi: 10.1093/oxfordhb/9780195336467.013.009.

26. Sáry P (2019) Water law rules in ancient Rome, Journal of Agricultural and Environmental Law 14(26), pp. 219-236, https://doi.org/10.21029/JAEL.2019.26.219

27. Van Den Bergh R (1999) Roman origins of environmental law?, Journal of South African Law 24(3), pp. 495-507.

28. Wacke A (2002) Protection of the Environment in Roman Law?, Roman Legal Tradition 1, pp. 1-24. 